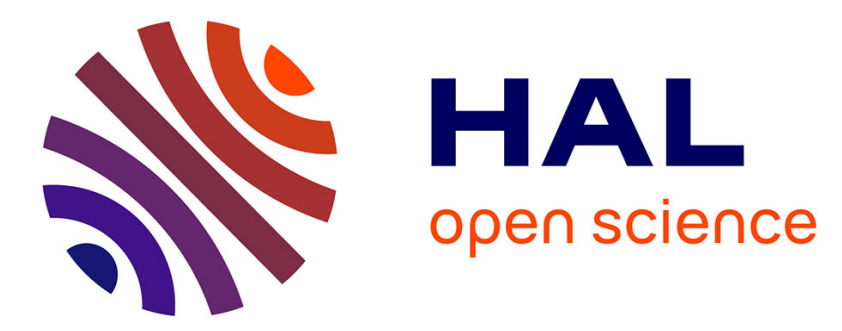

\title{
Plant traits and population characteristics predict extinctions in a long-term survey of Mediterranean annual plants
}

Arne Saatkamp, Laurence Affre, Thierry Dutoit, Peter Poschlod

\section{To cite this version:}

Arne Saatkamp, Laurence Affre, Thierry Dutoit, Peter Poschlod. Plant traits and population characteristics predict extinctions in a long-term survey of Mediterranean annual plants. Biodiversity and Conservation, 2018, 27, pp.2527-2540. 10.1007/s10531-018-1551-9 . hal-01915740

\author{
HAL Id: hal-01915740 \\ https://hal.science/hal-01915740
}

Submitted on 8 Nov 2018

HAL is a multi-disciplinary open access archive for the deposit and dissemination of scientific research documents, whether they are published or not. The documents may come from teaching and research institutions in France or abroad, or from public or private research centers.
L'archive ouverte pluridisciplinaire HAL, est destinée au dépôt et à la diffusion de documents scientifiques de niveau recherche, publiés ou non, émanant des établissements d'enseignement et de recherche français ou étrangers, des laboratoires publics ou privés. 


\title{
Plant traits and population characteristics predict extinctions in a long-term survey of Mediterranean annual plants
}

\author{
Arne Saatkamp ${ }^{1} \cdot$ Laurence Affre $^{1} \cdot$ Thierry Dutoit $^{1} \cdot$ Peter Poschlod $^{2}$
}

\begin{abstract}
Global and local environmental changes lead to frequent plant extinctions many of which occur in man-made habitats such as agricultural fields. Plant traits and site conditions modify risks of extinction, but strength and sense of their effect are not known yet. Here, we present a long-term survey of population sizes for Mediterranean annual plants that we revisited 20 years after their first record to evaluate climate, population size, traits and habitat requirements as drivers of local extinctions. Small populations had an increased probability of extinction in our data-set. Our analyses revealed that seed production and survival of seeds in the soil seed bank decreased extinction rate, whereas plant size increased extinction probability. Mean annual temperature increased extinction rates of annual plants in cereal fields. We discuss these effects as a response to recent and ongoing habitat changes, and discuss how traits may be used to guide conservation practices in the face of local extinctions.
\end{abstract}

Keywords Plant size $\cdot$ Seed banks $\cdot$ Local extinction $\cdot$ Seed number $\cdot$ Specific leaf area 


\section{Introduction}

Global environmental changes such as climate warming, changing land use and habitat fragmentation are identified as major reasons for the decline of plant diversity (Bobbink et al. 1998; Rogers et al. 2008; Römermann et al. 2008; Van Calster et al. 2008; Wiegmann and Waller 2006). However, plants differ in their specific extinction risks according to their functional traits (Farnsworth and Ogurcak 2008; Fréville et al. 2007; Kahmen et al. 2002; Lavergne et al. 2006; Ozinga et al. 2008; Piqueray et al. 2011; Römermann et al. 2008). Moreover, works on plant communities showed how traits interact with environment to trigger different extinction risks among plant species (Fréville et al. 2007; Kahmen et al. 2002; Römermann et al. 2009). Traits identified to trigger major population biological functions include specific leaf area (SLA), plant height, seed size and flowering date, interacting with management, habitat size and nutrient level (Fréville et al. 2007; Kahmen et al. 2002; Römermann et al. 2009). Works on regional scales suggest that relevant traits to explain interspecific differences in extinction risk depend on specific environmental conditions (Fréville et al. 2007; Lavergne et al. 2006; Ozinga et al. 2008; Rogers et al. 2008; Römermann et al. 2008; Wiegmann and Waller 2006). However direction and strength of effects of functional traits on extinction are not well known.

Indeed, relevant effects of traits might be detected when comparing local habitat and population properties, such as population size and mating system, which both have strong effects on population genetic structure (Duminil et al. 2007; Ellstrand 1992). Moreover, the identification of intrinsic risk factors (traits) for extinction in plants also enables to identify the relevant processes that determine local extinction risk. Therefore, one way to generalize results of extinction risks linked to declining populations across sites is to study specifically functional traits together with population sizes and environmental conditions.

Environmental conditions can change in an unidirectional way driving species to extinction, e.g., through changed disturbance regimes in anthropogenic habitats such as arable fields (Fried et al. 2009a). Environment also show temporal variability that may enhance coexistence of populations via storage effect which is linked to specific plant traits (Facelli et al. 2005; Levine and Rees 2004). Both processes can concern the same factor (e.g., soil moisture) and may be on the same temporal scale (years). For example, soil moisture can directly decrease seed populations in the soil via increasing fungal attack (Blaney and Kotanen 2001; Saatkamp et al. 2014; Schafer and Kotanen 2003). Other factors such as higher nutrient availability and warming of climate have also been shown to change plant community composition and diversity (Bobbink et al. 1998). Thus, directional changes in soil moisture, temperature and nutrient status are interacting with plant traits to influence extinction dynamics of populations for annual plants (Fréville et al. 2007).

Population characteristics known to correlate with extinction risk are population size, genetic structure and diversity. For example, population size influences local extinction, with small populations going extinct faster than large ones (Matthies et al. 2004). Since this makes it difficult to disentangle which factors finally drive a local plant population to extinction, we suggest in this study to use both, plant traits as well as environmental factors and population size in order to go further in the understanding of local plant extinctions. Plant traits can directly modify population dynamics (Angert et al. 2007; Gardarin et al. 2010), for example, adaptations at the seed level and soil seed mortality changes population size of annual plants (Adams et al. 2005; Kalisz and McPeek 1993; Menges 2000; Schmid and Matthies 1994). This extinction risk can be related to their short life cycle, differences in survival in the soil seed bank and to anthropogenic disturbances (Saatkamp 
et al. 2011a, 2014). This also separates seed mortality from seed number, in a trade-off with seed size, and hence separates mortality sources in the seed life stage from those in other life stages (Leishman et al. 2000; Moles et al. 2004; Saatkamp et al. 2009). Finally, the rarity of a plant species at larger spatial scales influences its extinction risk, since colonization events strongly depend on abundance of species in the seed rain arriving from larger distances (Hubbell 2001). However, until now, soil seed mortality and seed production have not been clearly separated in their effects on local extinction risk in annual plants (Saatkamp et al. 2009).

Differences in competitive ability among plants as estimated by plant size (Fayolle et al. 2009) or differences in recovery after disturbances related to relative growth rate tightly linked to specific leaf area (Shipley 2006), may help to further understand which processes lead to increased local extinction risk. Finally, also population genetic structure is related to plant traits (Duminil et al. 2007; Ellstrand 1992) and traits might affect extinctions in this way. For instance, the pollen:ovule $(\mathrm{P} / \mathrm{O})$ ratio is an indicator trait that relates to gene exchange via breeding system and realized pollination events (Cruden 1977; Loveless and Hamrick 1984), for which we showed elsewhere a link to other risk factors such as land use changes (Lhotte et al. 2014). The P/O ratio also retraces a gradient from low pollen exchanging and inbreeding to high pollen exchanging and obligate outcrossing species (Cruden 1977; Loveless and Hamrick 1984). In the context of rapidly changing habitat conditions, pollination can be a key factor for plants to adapt rapidly and hence we hypothesize that the $\mathrm{P} / \mathrm{O}$ ratio is in this way a factor that influences independently the risk of plant population extinctions.

Annual plants make up one third of plant diversity in the European Mediterranean region and are at comparatively high risks of extinction (Médail and Verlaque 1997). This extinction risk can be related to their short life cycle, important differences in survival in the soil seed bank and to their habitats typically with strong anthropogenic disturbances (Saatkamp et al. 2011a, 2014). Despite its importance in species number, we know strikingly little about the specific processes for the decline of annual plants in the Mediterranean region. Works that evaluated the relation between traits and local population dynamics or extinctions, did so for a single species (Adams et al. 2005; Kalisz and McPeek 1993). It is therefore expected that comparative analyses of population dynamics for several species will give new insights (Menges 2000). For annual plants of cereal fields, population extinctions are due to changing agricultural practices such as herbicide and fertilizer application as well as higher densities of crop plants (Fried et al. 2009b; Schneider et al. 1994). Annual plants react faster to environmental changes compared to perennial plants and thus effects are easier to detect. Therefore, annual plants in cereal fields give a good opportunity to test the effects of life history traits and habitat requirements on population dynamics.

In this study, we used data on populations for 24 rare and common arable plants together with novel and detailed experimental data on plant traits and environmental parameters to assess local extinction risk in plants. Our approach was to quantify at the same time influence of environmental factors, such as mean annual temperature, population size at the growing sites and characteristics at the species level such as plant traits and habitat requirements.

More specifically, we wanted to answer (i) how plant traits (especially seed production, survival in soil seed bank, seed mass, plant size, SLA and P/O ratio) and population size influence local extinction risk at the long run; (ii) how site climate influences extinction risks; (iii) how water, nutrient, light and temperature requirements as measured by Ellenberg's indicator values influence extinction and (iv) to finally analyse if plants that are rare on regional scales have a higher local extinction risk. 


\section{Materials and methods}

\section{Study site and species}

We gathered data on rare and common cereal weeds in an area of ca. $2500 \mathrm{~km}^{2}$ around the Luberon ridge in South Eastern France. Traditional agriculture in this area maintained a high diversity of rare arable plants elsewhere extinct in Europe and data have been gathered in the mid-1980s during field surveys (Filosa 1997). Based on surveys from 1983 to 1985, we revisited populations for 24 species (Supplementary Fig. 1) of rare arable plants. We also used data on rarity levels from a regional flora (Jauzein 1995) to categorise species into either rare or common (Table 1). Nomenclature followed Jauzein (1995).

\section{Climatic variables}

Since sites were scattered over large areas without nearby weather stations, we used the worldclim data set together with DIVA-GIS software (Hijmans et al. 2005) to extract climatic variables for our study sites. Study sites were spaced by more than $1 \mathrm{~km}$ in most

Table 1 Species studied, plant family, rarity class (Jauzein 1995), IUCN red-list classification for SouthEastern France (Noble et al. 2015): LC least concern, $V U$ vulnerable, $N T$ near threatened and number of populations studied

\begin{tabular}{|c|c|c|c|c|}
\hline Species & Family & Rarity & IUCN & Populations \\
\hline Adonis аппиа & Ranunculaceae & $\mathrm{R}$ & $\mathrm{LC}$ & 21 \\
\hline Adonis flammea & Ranunculaceae & $\mathrm{C}$ & $\mathrm{LC}$ & 33 \\
\hline Agrostemma githago & Caryophyllaceae & $\mathrm{R}$ & $\mathrm{LC}$ & 9 \\
\hline Androsace maxima & Primulaceae & $\mathrm{R}$ & $\mathrm{LC}$ & 7 \\
\hline Bifora radians & Apiaceae & $\mathrm{C}$ & $\mathrm{LC}$ & 17 \\
\hline Bifora testiculata & Apiaceae & $\mathrm{R}$ & NT & 5 \\
\hline Bupleurum rotundifolium & Apiaceae & $\mathrm{C}$ & $\mathrm{LC}$ & 3 \\
\hline Camelina microcarpa & Brassicaceae & $\mathrm{R}$ & LC & 2 \\
\hline Centaurea cyanus & Asteraceae & $\mathrm{R}$ & $\mathrm{LC}$ & 16 \\
\hline Cnicus benedictus & Asteraceae & $\mathrm{R}$ & $\mathrm{LC}$ & 17 \\
\hline Conringia orientalis & Brassicaceae & $\mathrm{R}$ & NT & 16 \\
\hline Consolida regalis & Ranunculaceae & $\mathrm{C}$ & $\mathrm{LC}$ & 1 \\
\hline Hypecoum pendulum & Papaveraceae & $\mathrm{R}$ & VU & 3 \\
\hline Legousia hybrida & Campanulaceae & $\mathrm{R}$ & $\mathrm{LC}$ & 5 \\
\hline Legousia speculum-veneris & Campanulaceae & $\mathrm{C}$ & $\mathrm{LC}$ & 4 \\
\hline Myagrum perfoliatum & Brassicaceae & $\mathrm{R}$ & $\mathrm{LC}$ & 2 \\
\hline Neslia apiculata & Brassicaceae & $\mathrm{C}$ & $\mathrm{LC}$ & 32 \\
\hline Nigella damascena & Ranunculaceae & $\mathrm{C}$ & $\mathrm{LC}$ & 1 \\
\hline Papaver argemone & Papaveraceae & $\mathrm{R}$ & $\mathrm{LC}$ & 14 \\
\hline Papaver hybridum & Papaveraceae & $\mathrm{R}$ & $\mathrm{LC}$ & 13 \\
\hline Ranunculus falcatus & Ranunculaceae & $\mathrm{R}$ & NT & 19 \\
\hline Roemeria hybrida & Papaveraceae & $\mathrm{R}$ & VU & 10 \\
\hline Turgenia latifolia & Apiaceae & $\mathrm{R}$ & NT & 28 \\
\hline Vaccaria hispanica & Caryophyllaceae & $\mathrm{R}$ & NT & 12 \\
\hline
\end{tabular}


cases, translating differences in climate into variance in the data-set. Our study region is characterised by Mediterranean climate with mean annual rainfall varying between 596 and $636 \mathrm{~mm}$, with maxima in April and October. We reduced the manifold climatic variables to mean annual temperature (MAT), since this variable reflects the main gradient in a principal component analysis (PCA) using all climatic variables, and which opposed lowland to upland sites. The first axis of the PCA explained $78 \%$ of variance, with MAT and all temperature variables being positively correlated to the first axis and annual precipitation and precipitation variables negatively related except precipitation seasonality; MAT and annual precipitation were strongly negatively correlated $\left(\mathrm{R}^{2}=0.99, \mathrm{p}<0.001\right)$. MAT varied from $8{ }^{\circ} \mathrm{C}$ in upland to $13{ }^{\circ} \mathrm{C}$ in lowland sites.

\section{Population size and local extinction}

We used a census data set on rare cereal weeds dating from 1983 to 1985 to gather population sizes and localisations (Filosa 1989). For our analyses we pooled data from 1983 to 1985. In 2005 and 2006 we revisited populations of 24 different plant species. For 290 populations, their size in terms of numbers of individuals has been documented in detail in 1983/1985. These old population sizes enabled us to study its effect on extinction: 192 went extinct and 98 remained stable. The populations were documented by one visit per year at the flowering to fruiting time of the species before wheat harvest. This corresponds to the visits of the initial data collection (D. Filosa, pers. comm.). The census was conducted at the same level of precision as in 1983. For comparison with the 1983 and 1985 data, we also pooled data from 2005 to 2006. In all analyses, we used presence/absence of populations in 2005/2006 as dependent variable. Evidently, the absence of a population in one single year does not equal extinction, since it might be still present in the soil seed bank and this for years (Saatkamp et al. 2009). However, we think that pooling the data over two years of inventory limits the amount of unobserved but still present populations, and that absence of populations in two consecutive years is a reasonable indicator of potential local extinction.

\section{Pollen:Ovule ratio}

In spring and summer 2006, we collected three stamens per flower bud, and one bud for each of five randomly chosen individuals for all 24 plant species (illustrated in Supplementary Fig. 1). We stored the three stamens for each bud dry together in Eppendorf tubes. The remaining flower was conserved in $70 \%$ alcohol in plastic tubes until we counted number of stamens and ovules. Once all species sampled, we dissolved stamen tissue using $550 \mu \mathrm{l}$ of sulphuric acid per tube for 24-48 h. After that, we crushed the remaining tissues with a small glass pestle, added $1650 \mu \mathrm{l}$ of water with $2 \%$ triton tenside and mixed it. We then centrifuged for $5 \mathrm{~min}$ and decanted the superfluous liquid. We added $1000 \mu \mathrm{l}$ of alcohol (95\%) and mixed it again. We centrifuged again for $5 \mathrm{~min}$, removed liquid, and dried to obtain dry pollen samples. We then added $40 \mu \mathrm{l}$ of a $30 \%$ sucrose $/ 20 \%$ glycerol solution ('counting solution') and sonicated the solution. We counted pollen grains under a microscope using a $1 \mu \mathrm{l}$ hematocytometer. We counted ovules under a binocular microscope. We then calculated the number of pollen grains for one stamen as follows: number of pollen grains in $1 \mu \mathrm{l} \times 40 \mu \mathrm{l}$ of counting solution, divided by the three stamens used. We then calculated pollen:ovule ratio $(\mathrm{P} / \mathrm{O})$ as the number of pollen grains for one stamen $\times$ number of stamens per flower, divided by the total number of ovules (Cruden 1977). 


\section{Seed production, seed mass and plant size}

We counted ripe seeds produced for 10 individual plants per species in the field. For species with multi-seeded fruits or infructescences, we counted the number of fruits or infructescences and sampled two of them per individual to count number of seeds per fruit/infructescence. Seed production per individual was then calculated as mean seed number per fruit/infructescences multiplied by the number of fruits/infructescences counted per individual. In our analyses, we used mean seed production for ten individuals as specific trait value. To measure seed mass for each species, we counted three replicates of 10 seeds and weighed them with an analytical balance $( \pm 0.001 \mathrm{mg})$. At the time of fruiting, we measured plant size (in $\mathrm{mm}$ ) in the field for 25 individuals chosen randomly in the population, to calculate mean plant size per species.

\section{Soil seed mortality}

We studied soil seed mortality using a burial experiment presented in more detail in Saatkamp et al. (2009). For each species, we collected in the field seed material between June and September 2005. We mixed the ripe seeds from at least 10 individuals and stored them dry in paper bags until burial in October 2005. After burial of seeds in nylon mesh bags in a randomised block design (five block replicates), we retrieved buried seeds after 6, 12, 18, 24 and 30 months of burial from October 2005 to April 2008. We determined the viable fraction for every seed lot including an initial value before burial, by using germination tests in a growth chamber and tetrazolium test for remaining seeds (I.S.T.A 1996). This burial experiment yielded mean mortality percentages for a 2.5 year period.

\section{Specific leaf area (SLA)}

Leaf material was collected in field on living individuals at begin of flowering (April to June 2007 and 2008) using only green, intact and undamaged leaves. For each species, five individual plants were chosen at random. Two leaves were collected per plant. Until measurement, we put leaves in sealed plastic bags stored at $4{ }^{\circ} \mathrm{C}$, and processed them within $24 \mathrm{~h}$ after collection according to the recommendations in Garnier et al. (2001). We measured leaf area only on living and fully turgescent leaves. We used scanned images along with reference surfaces of known size to detect leaf area using the lafore-software package (Lehsten 2005). We then placed leaves in tagged paper bags and dried them at $50{ }^{\circ} \mathrm{C}$ for 3 days. We measured dry leaf weight using a fine balance $( \pm 0.001 \mathrm{mg})$. SLA was calculated for each single leaf as the ratio of fresh leaf area on leaf dry mass. We then used the mean SLA values as plant trait in our analyses.

\section{Ellenberg indicator values}

Ellenberg et al. (1992) provided position of a species in gradients of light (L), temperature $(\mathrm{T})$, moisture $(\mathrm{F})$ and nutrients $(\mathrm{N})$ for the central European flora. Indicator values are a very sensible way to characterize habitat conditions for plants (Diekmann 2003; Saatkamp et al. 2011b). We complemented indicator values for Nigella damascena, using information 
from local floras (Jauzein 1995; Molinier 1981). All trait data are presented in the Supplementary Table 1.

\section{Statistical analyses}

Since our data was organized according to three levels of aggregation (populations, sites and species), we run three separate analyses for each level of aggregation i.e.: (1) population size, (2) mean annual temperature aggregated at the site level and (3) plant traits as well as Ellenberg indicator values aggregated at the species level. We first applied a generalized linear regression (GLM) analysis on the three levels of aggregation-populations, sites and species-separately. For the first two levels, we used extinction (1) versus persistence (0) of each population as a binary response variable in a GLM to evaluate effects of population size and site climate and functional traits. All explanatory variables were standardised prior to analyses.

For the species level we used a binomial GLM with logit link (logistic regression) with number of persistence and extinction as success/failure response variable. At the species level we had 24 species and 11 potential explanatory variables, part of which were correlated. We therefore reduced explanatory variables to three use a PCA in the following way. For each of three first PCA-axes with proportions explained variance of $0.25,0.22$ and 0.16, we selected the variable with the highest loading. This retained plant size (PS, loading -0.51 on PCA1), seed number (SN, loading 0.54 on PCA2) and seed bank survival (SB, loading -0.55 on PCA3). Explanatory variables were not correlated according to Pearson's correlation coefficient $(r<0.5)$. We then fitted GLM using the glm module in $\mathrm{R}$. The use of species as independent data points is controversial since closely related species show similar features because of common ancestry. In our data set, where several major phylogenetic lineages are represented by only a few representatives, and with many closely related species pairs (Table 1) with contrasting traits, we think it is not reasonable to expect phylogenetic 'bias' in the data, which would further be difficult to quantify with such a small set of species. Therefore we did not perform an analysis including species groupings as random effects.

In supplementary document 1 , we also present a single analysis, a generalized mixed model (GLMM) with sites and species as random factors and including all levels of aggregation in a single analysis. This file also contains a model selection process. We used GLMM with residual maximum likelihood (REML) in the R package lme4 (Bates and Maechler 2010; R-Core-Team 2014). As outlined above, we were not interested to study explicitly phylogenetic signals in extinction risk and did not include a complete covariance matrix on phylogenetic relations among our species in our GLMM analysis.

Independently from that, we tested whether rarity had an effect on local extinction risk using GLMM with sites and species as random effects.

\section{Results}

\section{Effect of population size on extinction}

First we analysed the effect of population size on extinction, which showed a highly significant negative effect of population size on extinction in a binomial GLM with a population size effect of $-0.4869(\mathrm{SE}=0.1342, \mathrm{z}=-3.630, \mathrm{p}<0.001, \mathrm{AIC}=360.84)$. This result 

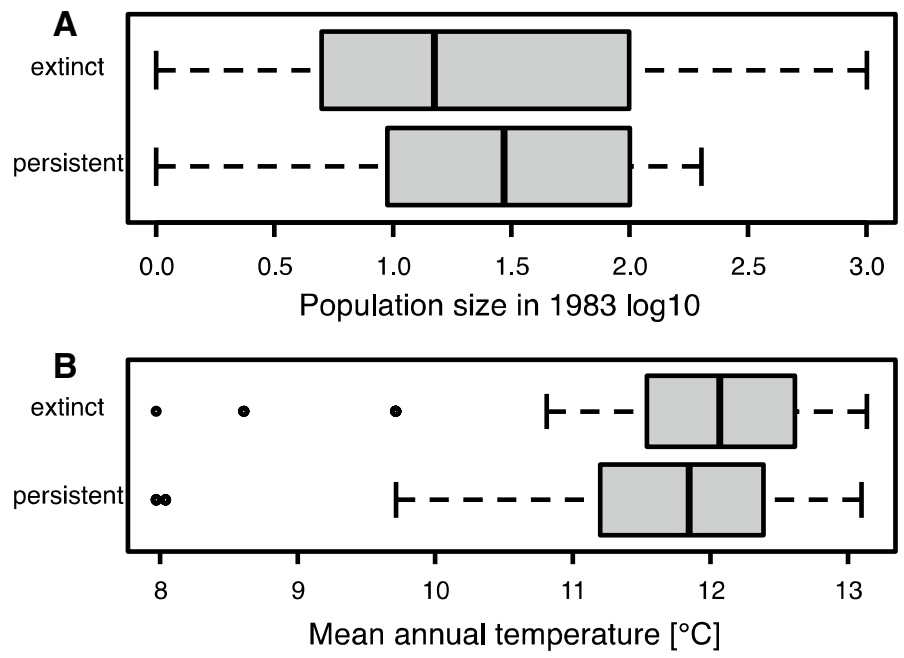

Fig. 1 Effect of population size and mean annual temperature on extinctions; note that the dependant variable extinct/persistent was used for grouping and the logarithmic scale for population size

was confirmed in a GLMM with site and species as random factor and population size as fixed factor with a slope of $-0.8954(\mathrm{SE}=0.2305, \mathrm{z}=-3.885, \mathrm{p}<0.001, \mathrm{AIC}=329.8)$. The larger population size the lower was the extinction risk (Fig. 1A).

\section{Effect of mean annual temperature (MAT) on extinction}

We then analysed the effect of MAT separately on extinctions in a binomial GLM, which showed a positive effect of temperature on extinction (slope $0.4354, \mathrm{SE}=0.1467, \mathrm{z}=2.968$, $\mathrm{p}=0.003$, AIC 365.6), i.e. more extinctions in warmer sites. We also run a GLMM, including sites and species as random factor, which showed a positive effect of temperature on extinction (slope $=0.5531, \mathrm{SE}=0.2315, \mathrm{z}=2.389, \mathrm{p}=0.017, \mathrm{AIC}=344.3$ ). Overall, high mean annual temperature increased local extinction, with more extinctions being in warmer lowland sites (Fig. 1B).

\section{Effect of traits and Ellenberg values on extinctions}

The principal component analysis (PCA) combining all plant traits and Ellenberg indicator values showed that a number of traits and Ellenberg values were correlated across our data-set of 24 species (Fig. 2). The first three axes with a cumulative proportion of variance of $63 \%$ identified a set of plant traits explaining variance between species with the first principal component (PC1) being negatively related to plant size (PS, loading -0.51 on PC1) and seed mass (SM, - 0.34) and positively to Ellenberg's temperature (T, 0.46) and moisture $(\mathrm{F}, 0.33)$ values, the second component being positively related to seed number (SN, loading 0.54 on PC2) and negatively to seed mass (SM, - 0.44) and the third to seed bank survival (SB, loading -0.55 on PC3) and negatively to Ellenbergs's nutrient value $(\mathrm{N},-0.44)$.

Based on the PCA we retained the three plant traits that were most related to the first three PCA axes as uncorrelated explanatory variables, which we used in a GLM with a 


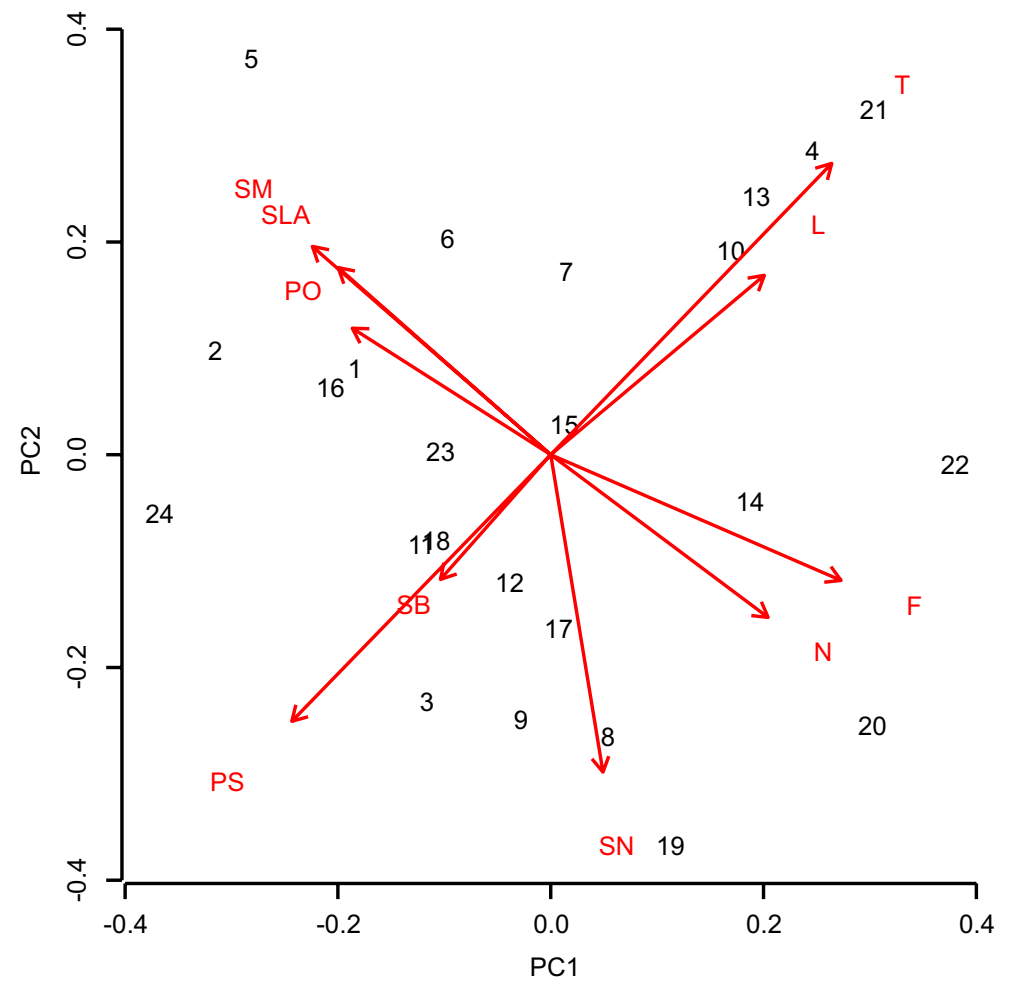

Fig. 2 Principal Componant Analysis of plant traits and Ellenberg indicator values of the studied species ( $S B$ seed bank survival; $S N$ seed number, $S M$ seed mass, $P S$ plant size, $S L A$ specific leaf area, Ellenberg's moisture $(F)$, temperature $(T)$, light $(L)$ and nutrient $(N)$ value, $P O$ pollen:ovule ratio)

Table 2 Effects of plant size, seed number and seed bank survival on extinction in a logistic GLM; variables where standardised prior to analysis

\begin{tabular}{lrrr}
\hline Explanatory variables & Estimate \pm SE & z value & $p$ \\
\hline Plant size (PS) & $0.2853 \pm 0.1442$ & 1.978 & $0.0479 *$ \\
Seed number (SN) & $-0.3560 \pm 0.1460$ & -2.438 & $0.0148^{*}$ \\
Survival in soil seed bank (SB) & $-0.2800 \pm 0.1420$ & -1.971 & $0.0487^{*}$ \\
\hline
\end{tabular}

The model was extinctions/persistence $\sim \mathrm{PS}+\mathrm{SN}+\mathrm{SB}$, where $P S$ plant size, $S N$ seed number, $S B$ seed bank survival

logit link (logistic regression). We performed this GLM on data aggregated at the species level in order to analyse the persistence/extinction as success/failure presented in Table 2.

This GLM showed a negative effect of seed number on the persistence/extinction ratio with highly productive species beeing less exposed to extinctions compared to species with reduced seed production (Table 2). There were positive effects of plant size on the persistence/extintions ratio, large plants having a higher probability of extinction than small plants (Table 2). The negative effect of survival in the soil seed bank 
Fig. 3 Local extinction risk of populations $(n=290)$ for 24 species according to their frequency at the regional level (GLMM, Wald's $\mathrm{z}=3.358, \mathrm{p}<0.001$ )

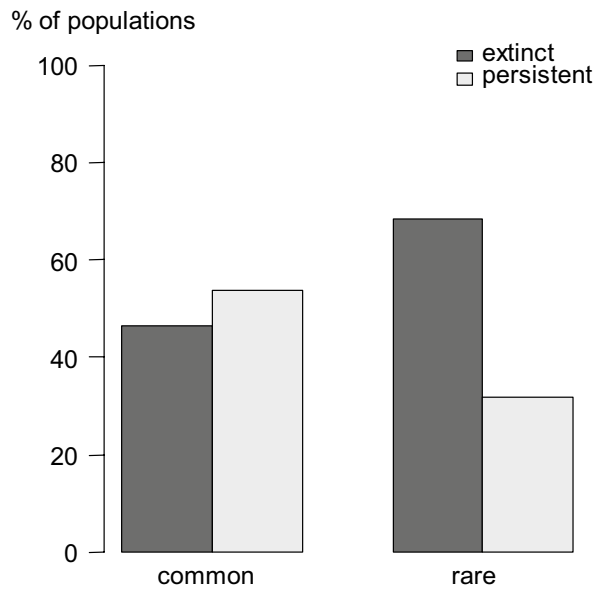

on persistence reflects the fact that species with seed that survived well in our 2.5 year burial experiment had a lower probability of extinction of their populations (Table 2).

The GLMM analysis presented in Fig. 3 revealed that there was a highly significant effect of species' rarity status on extinction events with sites and species as random effects. Species that were rare at a larger scale showed higher proportion of local extinctions than species that were common.

\section{Discussion}

Our approach and our data highlighted for the first time that local plant population extinction is related to plant traits, niches and site conditions; with significant effects of population size, position in a climatic gradient, habitat requirements and plant traits.

One of the strongest effects on local population extinction was that smaller populations went extinct more easily than larger ones. This is additional evidence for the higher extinction risk of small populations - a well-known phenomenon but with little empirical evidence- (but see e.g. Fischer and Stöcklin 1997; Matthies et al. 2004). The higher extinction risk of smaller populations has potentially three causes: (i) higher influence of stochastic events in reproduction, growth and mortality, (ii) high impact of stochastic deterioration of the environment (Menges 1998) (iii) consequences of reduced fitness due to limited genetic diversity, caused by inbreeding, accumulation of deleterious mutations and genetic drift (Ellstrand and Elam 1993).

Additionally, there were more local extinctions of annual plants in warmer sites as indicated by mean annual temperature (MAT) in our analysis. MAT is higher in lowland areas, where summer drought is stronger and vegetation period shorter. However, lowland sites tend also to be subjected to heavier intensification of agriculture, fragmentation and urbanisation since they are close to growing urban areas. Would temperature have increased strongly, species should have disappeared in the warmest sites according to their temperature requirements. These analyses including indicator values (Ellenberg et al. 1992) suggest that changes affect lowland sites which harbour temperature demanding species, but our data did not specifically highlight temperature demanding species to disappear first. 
The most important variance in plant traits explaining population extinction was related to seed number and seed mass. Populations of species with a high seed production showed decreased probability of extinction compared to plants with low seed production. Seed production was associated with the second principal component in our PCA (Fig. 2), reflecting the well known seed number-size trade-off (Moles and Westoby 2006), and negatively related to seed mass. It has repeatedly been shown that higher seed production is associated with frequent disturbances (Pakeman et al. 2008) and that large seeded plants are particularily endangered by the disappearance of effective dispersers (Poschlod et al. 2013). Our data suggest that changes in the disturbance regime and habitat of mediterranean cereal fields favour small seeded highly productive plants and that species with large seeds and low seed production are at higher risk of extinction.

Plant size was positively associated with extinction probability on our analysis (Table 2) indicating that large plants are at higher risk of extinction. This can be related to competition between arable weeds and wheat (Dutoit et al. 2001) and can be linked to the increasing stem density per square meter of cultivated cereals in our area. This suggests to use a management for less dense stands of extensive cereal fields, a causal relationship and recommendation that has already been elucidated for central Europe (Schneider et al. 1994). Density increased due to the application of manure, chemicals and herbicides that all increase productivity in cereal stands, which disadvantage plants adapted to low nutrient levels and lower cereal density (Storkey et al. 2012).

Survival of seeds in the soil seed bank was negatively associated with exctinctions, with plants that had high survival in our 2.5 year seed burial experiment having lower probabilities of extinctions. This is in line with a number of theoretical (Cohen 1966; Venable and Brown 1988) and empirical works (Stöcklin and Fischer 1999; Venable 2007) showing that soil seed banks play an important role to increase local persistence and decrease probability of extinction. In our data-set, species with low seed survival in the seed bank were at highest risk of extinction in mediterranean cereal fields. Together with data on seed production and seed size, this highlights the need of special attention to short-lived and large seeded plant species such as Agrostemma githago, Asperula arvensis or Vaccaria hispanica, being particularly endangered after current changes in land-use.

Altogether, our data support empirically the importance of interspecific differences in plant traits for extinction risk assessment (Menges 2000; Poschlod et al. 2000) and traces a way how environmental changes and traits can be used to quantify these extinctions and predict future extinctions. We therefore propose to integrate traits e.g. in population viability analyses for plants (Brigham and Schwartz 2003; Harrison and Ray 2002; Menges 2000). However, there are a number of complex interactions between traits, population size and site characteristics which cannot be studied with such a limited set of species in a multi-population survey and which would profit from analyses using larger data-sets on extinctions.

Furthermore, there are more extinction events in rare compared to widespread species. This can be related to dispersal limitation via seeds or pollen and therefore shows the importance of nearby other populations in a metapopulation for local extinctions of plants (Harrison and Ray 2002). Only recently it was shown that specialist arable plants declined stronger than non-specialist ones (Meyer et al. 2013). However, risks that already drove species to rarity in the past on a regional scale continued to act in the observation period and lead to the observed correlation of recent extinction and regional rarity. The relative rarity of small populations of plants with high soil seed mortality at the beginning of surveys indicates that past risks influenced the relative frequencies of species at the outset. Additionally, this extends previous analyses (Fréville et al. 2007; Lavergne et al. 2006) by 
focusing in a more detailed way on population extinctions and that help to identify underlying processes in order to better inform conservation efforts.

Acknowledgements We thank all farmers of the Luberon for access to their fields. We are very grateful to Pierre Frapa and Georges Guende (Parc Naturel Régional du Luberon) for funding and documentation and Frauke Behrendt (University of Brighton) for English language revision. AS benefited from the Région Provence Alpes Côte d'Azur grant "Gévoclé" and from funding through the GREAT-med programme under funding by the European Union Neighborhood Partnership Initiative (ENPI CBCMED). We thank two anonymous reviewers for many helpful comments.

\section{References}

Adams VM, Marsh DM, Knox JS (2005) Importance of the seed bank for population viability and population monitoring in a threatened wetland herb. Biol Conserv 124:425-436

Angert AL, Huxman TE, Barron-Gafford GA, Gerst KL, Venable DL (2007) Linking growth strategies to long-term population dynamics in aguild of desert annuals. J Ecol 95:321-331

Bates D, Maechler M (2010) Linear mixed-effect models using S4 classes. R package version 0.999375-35 2010

Blaney CS, Kotanen PM (2001) Effects of fungal pathogens on seeds of native and exotic plants: a test using congeneric pairs. J Appl Ecol 38:1104-1113

Bobbink R, Hornung M, Roelofs JGM (1998) The effects of air-borne nitrogen pollutants on species diversity in natural and semi-natural European vegetation. J Ecol 86:717-738

Brigham CA, Schwartz MW (2003) Population viability in plants. Ecol Stud 165:1-392

Cohen D (1966) Optimizing reproduction in a randomly varying environment. J Theor Biol 12:119-129

Cruden RW (1977) Pollen-ovule ratios-conservative indicator of breeding systems in flowering plants. Evolution 31:32-46

Diekmann M (2003) Species indicator values as an important tool in applied plant ecology—a review. Basic Appl Ecol 4:493-506

Duminil J, Fineschi S, Hampe A, Jordano P, Salvini D, Vendramin GG, Petit RJ (2007) Can population genetic structure be predicted from life-history traits? Am Nat 169:662-672

Dutoit T, Gerbaud E, Ourcival J-M, Roux M, Alard D (2001) Recherche prospective sur la dualité entre caractéristiques morphologiques et capacités de compétition des végétaux: le cas des espèces adventices et du blé. Comptes Rendus de l'Académie des Sciences-Series III-Sciences de la Vie 324:261-272

Ellenberg H, Weber HE, Düll R, Wirth V, Werner W, Paulissen D (1992) Zeigerwerte von Pflanzen in Mitteleuropa. Scr Geobot 18:1-258

Ellstrand NC (1992) Gene flow by pollen: implications for plant conservation genetics. Oikos 63:77-86

Ellstrand NC, Elam DR (1993) Population genetic consequences of small population size: implications for plant conservation. Ann Rev Ecol Syst 24:217-243

Facelli JM, Chesson PL, Barnes N (2005) Differences in seed biology of annual plants in arid lands: a key ingredient of the storage effect. Ecology 86:2998-3006

Farnsworth EJ, Ogurcak DE (2008) Functional groups of rare plants differ in levels of imperilment. Am J Bot 95:943-953

Fayolle A, Violle C, Navas ML (2009) Differential impacts of plant interactions on herbaceous species recruitment: disentangling factors controlling emergence, survival and growth of seedlings. Oecologia 159:817-825

Filosa D (1989) Les plantes messicoles dans le Parc Naturel Régional du Luberon et contrées limitrophesunpublished report, Conservatoire Botanique National Méditerranéen

Filosa D (1997) La régression des messicoles dans le Sud-Est de la France. In: Dalmas H (ed) Faut-il sauver les mauvaises herbes?. Conservatoire Botanique National Alpin, Gap-Charance, pp 67-74

Fischer M, Stöcklin J (1997) Local extinction of plants in remnants of extensively used calcareous grasslands 1950-1985. Conserv Biol 11:727-737

Fréville HA, McConway K, Dodd M, Silvertown J (2007) Prediction of extinction in plants: interaction of extrinsic threats and life history traits. Ecology 88:2662-2672. https://doi.org/10.1890/06-1453.1

Fried G, Chauvel B, Reboud X (2009a) A functional analysis of large-scale temporal shifts from 1970 to 2000 in weed assemblages of sunflower crops in France. J Veg Sci 20:49-58

Fried G, Petit S, Dessaint F, Reboud X (2009b) Arable weed decline in Northern France: crop edges as refugia for weed conservation? Biol Conserv 142:238-243 
Gardarin A, Guillemin JP, Munier-Jolain NM, Colbach N (2010) Estimation of key parameters for weed population dynamics models: base temperature and base water potential for germination. Eur J Agron 32:162-168

Garnier E, Shipley B, Roumet C, Laurent G (2001) A standardized protocol for the determination of specific leaf area and leaf dry matter content. Funct Ecol 15:688-695

Harrison S, Ray C (2002) Plant population viability and metapopulation-level processes. In: Beissinger S, McCullough DR (eds) Population viability analysis. University of Chicago Press, Chicago, pp 109-122

Hijmans RJ, Cameron SE, Parra JL, Jones PG, Jarvis P (2005) Very high resolution interpolated climate surfaces for global land areas. Int J Climatol 25:1965-1978

Hubbell SP (2001) The unified neutral theory of biodiversity and biogeography. Princeton University Press, Princeton

I.S.T.A (1996) (International Seed Testing Association) International rules for seed testing. Seed Science and Technology 24(suppl.) $335 \mathrm{pp}$

Jauzein P (1995) Flore des champs cultivés. INRA, Paris

Kahmen S, Poschlod P, Schreiber KF (2002) Conservation management of calcareous grasslands. Changes in plant species composition and response of functional traits during 25 years. Biol Conserv 104:319-328

Kalisz S, McPeek MA (1993) Extinction dynamics, population growth and seed banks. An example using an age-structured annual. Oecologia 95:314-320

Lavergne S, Molina J, Debussche M (2006) Fingerprints of environmental change on the rare Mediterranean flora: a 115-year study. Global Change Biol 12:1466-1478

Lehsten V (2005) Functional analysis and the modelling of vegetation. PhD Thesis, Universität Oldenburg

Leishman MR, Wright IJ, Moles AT, Westoby M (2000) The evolutionary ecology of seed size. In: Fenner $\mathrm{M}$ (ed) Seeds - the ecology of regeneration in plant communities. CABI, Wallingford

Levine JM, Rees M (2004) Effects of temporal variability on rare plant persistence in annual systems. Am Nat 164:350-363

Lhotte A, Affre L, Saatkamp A (2014) Are there contrasted impacts of urbanization and land uses on population persistence? The case of Teucrium pseudochamaepitys, an endangered species in Southern France. Flora 209:484-490

Loveless MD, Hamrick JL (1984) Ecological determinants of genetic structure in plant populations. Ann Rev Ecol Syst 15:65-95

Matthies D, Bräuer I, Maibom W, Tscharntke T (2004) Population size and the risk of local extinction: empirical evidence from rare plants. Oikos 105:481-488

Médail F, Verlaque R (1997) Ecological characteristics and rarity of endemic plants from southeast France and Corsica: implications for biodiversity conservation. Biol Conserv 80:269-281

Menges ES (1998) Evaluating extinction risks in plant populations. In: Fiedler PL, Kareiva PM (eds) Conservation biology for the coming decade. Chapman and Hall, New York, pp 49-65

Menges ES (2000) Population viability analyses in plants: challenges and opportunities. Trends Ecol Evol $15: 51-56$

Meyer S, Wesche K, Krause B, Leuschner C (2013) Dramatic losses of specialist arable plants in Central Germany since the 1950s/60s-a cross-regional analysis. Divers Distrib 19:1175-1187

Moles AT, Westoby M (2006) Seed size and plant strategy across the whole life cycle. Oikos 113:91-105

Moles AT, Falster DS, Leishman MR, Westoby M (2004) Small-seeded species produce more seeds per square metre of canopy per year, but not per individual per lifetime. J Ecol 92:384-396

Molinier R (1981) Catalogue des plantes vasculaires des Bouches-du-Rhône. Muséum d'Histoire Naturelle Marseille, Marseille

Noble V, Van Es J, Michaud H, Garraud L (2015) Liste Rouge de la flore vasculaire de Provence-Alpes-Côte d'Azur. DREAL Provence-Alpes-Côte d'Azur, Aix-en-Provence, France

Ozinga WA et al (2008) Dispersal failure contributes to plant losses in NW Europe. Ecol Lett 11:1-9

Pakeman RJ et al (2008) Impact of abundance weighting on the response of seed traits to climate and land use. J Ecol 96:355-366

Piqueray J, Bisteau E, Cristofoli S, Palm R, Poschlod P, Gg Mahy (2011) Plant species extinction debt in a temperate biodiversity hotspot: community, species and functional traits approaches. Biol Conserv 144:1619-1629

Poschlod P, Kleyer M, Tackenberg O (2000) Databases on life history traits as a tool for risk assessment in plant species. Zeitschrift für Ökologie und Naturschutz 9:3-18

Poschlod P, Abedi M, Bartelheimer M, Drobnik J, Rosbakh S, Saatkamp A (2013) Seed ecology and assembly rules in plant communities. Vegetation ecology, 2nd edn. Wiley-Blackwell, Chichester

R-Core-Team (2014) R: A language and environment for statistical computing. R Foundation for Statistical Computing, Vienna 
Rogers DA, Rooney TP, Olson D, Waller DM (2008) Shifts in southern Wisconsin forest canopy and understorey richness, composition and heterogeneity. Ecology 89:2482-2492. https://doi. org/10.1890/07-1129.1

Römermann C, Tackenberg O, Jackel AK, Poschlod P (2008) Eutrophication and fragmentation are related to species' rate of decline but not to species rarity: results from a functional approach. Biodivers Conserv 17:591-604

Römermann C, Bernhardt-Römermann M, Kleyer M, Poschlod P (2009) Substitutes for grazing in seminatural grasslands-do mowing or mulching represent valuable alternatives to maintain vegetation structure? J Veg Sci 20:1086-1098

Saatkamp A, Affre L, Dutoit T, Poschlod P (2009) The seed bank longevity index revisited: limited reliability evident from a burial experiment and database analyses. Ann Bot 104:715-724

Saatkamp A, Affre L, Dutoit T, Poschlod P (2011a) Germination traits explain soil seed persistence across species: the case of Mediterranean annual plants in cereal fields. Ann Bot 107:415

Saatkamp A, Guyon M, Philippe M (2011b) Moss caulking of boats in upper French Rhône and Saône (Eastern France) from the 3rd to the 20th century and the use of Neckera crispa Hedwig. Veg Hist Archaeobot 20(4):293-304

Saatkamp A, Poschlod P, Venable DL (2014) The functional role of soil seed banks in natural communities. In: Gallagher RS (ed) Seeds-the ecology of regeneration in plant communities, vol 3. CABI, Wallingford, pp 263-294

Schafer M, Kotanen PM (2003) The influence of soil moisture on losses of buried seeds to fungi. Acta Oecol 24:255-263

Schmid B, Matthies D (1994) Seltenheit und Gefährdung-Populationsbiologische Grundlagen des Artenschutzes. Naturwissenschaften 81:283-292

Schneider C, Sukopp U, Sukopp H (1994) Biologisch-ökologische Grundlagen des Schutzes gefährdeter Segetalpflanzen. Bundesamt für Naturschutz, Bonn-Bad Godesberg

Shipley B (2006) Net assimilation rate, specific leaf area and leaf mass ratio: which is most closely correlated with relative growth rate? A meta-analysis. Funct Ecol 20:565-574

Stöcklin J, Fischer M (1999) Plants with longer-lived seeds have lower local extinction rates in grassland remnants 1950-1985. Oecologia 120:539-543

Storkey J, Meyer S, Still KS, Leuschner C (2012) The impact of agricultural intensification and land-use change on the European arable flora. Proc R Soc B 279:1421-1429

Van Calster H, Vandenberghe R, Ruysen M, Verheyen K, Hermy M, Decocq G (2008) Unexpectedly high 20th century floristic losses in a rural landscape in northern France. J Ecol 96:927-936

Venable DL (2007) Bet hedging in a guild of desert annuals. Ecology 88:1086-1090

Venable DL, Brown JS (1988) The selective interaction of dispersal, dormancy and seed size as adaptations for reducing risks in variable environments. Am Nat 131:360-384

Wiegmann SM, Waller DM (2006) Fifty years of change in northern upland forest understories: identity and traits of "winner" and "loser" plant species. Biol Conserv 129:109-123 